\title{
Characterization of Insulin-Like Growth Factor-I and Its Receptor and Binding Proteins in Transected Nerves and Cultured Schwann Cells
}

\author{
Hsin-Lin Cheng, Ann Randolph, *Douglas Yee, †Patrick Delafontaine, \\ Gihan Tennekoon, and Eva L. Feldman \\ University of Michigan Department of Neurology and Neuroscience Program, Ann Arbor, Michigan; *University of Texas \\ Health Science Center, San Antonio, Texas; and †Emory University, Atlanta, Georgia, U.S.A.
}

\begin{abstract}
The insulin-like growth factors (IGFs) are trophic factors whose growth-promoting actions are mediated via the IGF-I receptor and modulated by six IGF binding proteins (IGFBPs). In this study, we observed increased transcripts of both IGF-I and IGF-I receptor after rat sciatic nerve transection. Schwann cells (SCS) were the main source of IGF-I and IGFBP-5 immunoreactivity until 7 days after nerve transection, when invading macrophages in the distal nerve stumps were strongly IGF-I positive. In vitro, IGF-I promoted SC mitogenesis. Northern analysis revealed that SCs expressed IGF-I receptor and IGFBP-5. IGF-I treatment increased the intensity of IGFBP-5 without affecting gene expression. Des(1-3)IGF-I, an IGF-I analogue with low affinity for IGFBP, had no such effect. Incubation of recombinant human IGFBP-5 with SC conditioned media revealed IGF-I protection of IGFBP-5 from proteolysis, implying the presence of an IGFBP-5 protease in SC conditioned media. Collectively, these data support the concept that, in response to nerve injury, invading macrophages produce IGF-I and SC express the IGF-I receptor, to facilitate regeneration. This regenerative process may be augmented further by the ability of SC to secrete IGFBPs, which in turn may increase local IGF-I bioavailability. Key Words: Insulin-like growth factor-Receptor-Binding protein-Schwann cells-Nerve transection. J. Neurochem. 66, 525-536 (1996).
\end{abstract}

The insulin-like growth factors (IGF-I and IGF-II) are polypeptides with both growth-promoting and insulin-like metabolic activities (Krywicki and Yee, 1992). The mitogenic actions of both IGFs are mediated via the IGF-I receptor, a tyrosine kinase receptor whose activation results in both auto- and intracellular substrate protein phosphorylation (Chou et al., 1987). The actions of the IGFs are modulated by six structurally related proteins, the IGF binding proteins (IGFBPs) (Clemmons, 1991; Drop, 1992). The expression of IGFBPs varies by cell and tissue type
(Clemmons, 1991; Drop, 1992) and is regulated by hormones (Torring et al., 1991; Unterman et al., 1991) and growth factors (Martin and Baxter, 1991; Barreca et al., 1992), including IGF-I (Clemmons, 1991; Conover, 1991; Martin et al., 1992). The IGFBPs transport IGFs to target tissues (Binoux et al., 1991) and alter IGF binding to IGF receptors (McCusker et al., 1991). Secreted IGFBPs can also bind to extracellular surfaces and target IGFs to mediate growth in specific cell types. For example, in fibroblasts, IGFBP-5 associated with the extracellular matrix (ECM) augments IGF-I action, implying IGFBP-5 increases local access of IGF-I to the IGF-I receptor (Jones et al., 1993).

In the CNS, IGF, IGF receptor, and IGFBP expression is high during the fetal period (Beck et al., 1988; Clemmons, 1989; Daughaday and Rotwein, 1989; Sara and Hall, 1990; Liu et al., 1991), suggesting a role for these factors in normal development. During rat embryogenesis, IGF-I mRNA is detected in regions of active nerve sprouting, spinal ganglia, and facial target regions of the trigeminal nerve (Bondy et al., 1990). In humans, IGF-I is present in fetal and adult brain and in cerebrospinal fluid (Backstrom et al., 1984; Haselbacher et al., 1985; Han et al., 1988). In vitro, developing oligodendrocyte progenitor cells require IGF-I to progress to adult, myelin-forming oligodendrocytes (McMorris and Dubois-Dalcq, 1988; Mozell and McMorris, 1988). IGFs also enhance growth in a

Received June 26, 1995; revised manuscript received August 25, 1995; accepted September 8, 1995.

Address correspondence and reprint requests to Dr. E. L. Feldman at University of Michigan, Department of Neurology, 4414 Kresge III, Ann Arbor, MI 48109, U.S.A.

Abbreviations used: DMEM, Dulbecco's modified Eagle's medium; ECM, extracellular matrix; FBS, fetal bovine serum; IGF, insulin-like growth factor; IGFBP, insulin-like growth factor binding protein; MTT, 3-(4,5-dimethylthiazol-2-yl)-2,5-diphenyltetrazolium bromide; NGF, nerve growth factor; SC, Schwann cell; $\left[{ }^{3} \mathrm{H}\right]$ TdR, [ methyl- $\left.{ }^{3} \mathrm{H}\right]$ thymidine. 
variety of neuronal types, including sympathetic and dorsal root ganglia and cloned neuronal cell lines (Martin and Feldman, 1993; Sumantran and Feldman, 1993)

IGFs and IGFBPs also serve a role in tissue repair and regeneration (Skottner et al., 1990). IGFs are implicated in accelerated wound healing (Lynch et al., 1989; Steenfos and Jansson, 1992; Suh et al., 1992) and bone remodeling; IGFs modulate osteoblast proliferation and matrix formation (Skottner et al., 1990). IGFs enhance tissue regeneration, including pancreas (Smith et al., 1991), muscle (Jennische and Matejka, 1992 ), and kidney (Matejka and Jennische, 1992; Verstrepen et al., 1993). In the nervous system, IGF infusion enhances motor nerve regeneration (Sjoberg and Kanje, 1989; Near et al., 1992) and, in vitro, stimulates regeneration of adult sensory neurons (Fernyhough et al., 1993).

The pattern of IGF expression during nervous system development coupled with its role in repair of nonnervous system tissues lead us to ask whether IGFs and/or IGFBPs could play a facilitory role in nerve regeneration. As an initial step, we examined IGF-I and IGF-I receptor gene expression after sciatic nerve transection and observed increased transcripts for both factors in lesioned nerves. Schwann cells (SCs) were the main source of IGF-I immunoreactivity until 7 days after nerve transection, when macrophages containing high levels of IGF-I invaded the distal nerve stumps. To address further the role of the IGF axis in SC biology, we determined the in vitro expression pattern of the IGF-I receptor and the IGFBPs. Transfected MT4H1 rat SCs expressed the IGF-I receptor and two IGFBPs with molecular mass estimates of 24 and 31 $\mathrm{kDa}$. Addition of IGF-I resulted in SC mitogenesis and enhanced levels of IGFBP-5. We investigated further the mechanism by which IGF-I regulates IGFBP-5 expression and found that IGF-I protected IGFBP-5 from proteolysis. Collectively, these data support the concept that in response to injury, invading macrophages produce IGF-I and SC express the IGF-I receptor, to facilitate axonal regeneration. This regenerative process may be augmented further by the ability of $\mathrm{SC}$ to secrete IGFBPs, which in turn bind SC basement membrane and increase local IGF-I bioavailability.

\section{MATERIALS AND METHODS}

Dulbecco's modified Eagle's medium (DMEM) was purchased from GibcoBRL (Gaithersburg, MD, U.S.A.), fetal bovine serum (FBS) from Hyclone (Logan, UT, U.S.A.), and tissue culture supplies from Corning Glass Works (Corning, NY, U.S.A.) and Costar (Cambridge, MA, U.S.A.). Restriction enzymes were purchased from GibcoBRL and New England Biolabs (Beverly, MA, U.S.A.) and $\left[{ }^{32} \mathrm{P}\right]-$ dCTP from NEN Du Pont (Boston, MA, U.S.A.). All other chemicals were purchased from Sigma Chemical Co. (St. Louis, MO, U.S.A.)

\section{Sciatic nerve transection}

Using aseptic technique, the sciatic nerve of anesthetized (ketamine-rompun, $1 \mathrm{cc} / \mathrm{kg}$ ) adult Sprague-Dawley male rats (125-150 g; Spartan, Indianapolis, IN, U.S.A.) was exposed at the sciatic notch. After double ligation, the nerve was transected using fine scissors. The nerve stumps were sutured into adjoining muscles. At 3 or 7 days following surgery, the animals were killed by an overdose of ketaminerompun. Both the distal and proximal nerve stumps were removed, stripped of excess connective tissue, and immediately frozen in liquid nitrogen. The contralateral unlesioned sciatic nerve served as the control. Nerves from $10-12$ rats were pooled for each time point. All animal protocols were approved by the institutional animal care and use committee of the University of Michigan.

\section{cDNA probes}

A $300-b p$ rat IGFBP-5 cDNA (Dr. Shunichi Shimasaki, Whittier Institute, La Jolla, CA, U.S.A.), which encodes portions of the mature peptide, in pBluescript SK + plasmid was generated by SacII and HindIII digestion. The IGF-I receptor cDNA was a gift from Dr. Haim Werner (Bethesda, MD, U.S.A.). The cDNA was a 265-bp insert excised from pGEM3 by EcoRI and SmaI digestion. A 1.8-kb PstI-PstI fragment of a chicken $\beta$-actin was excised from pAct-1 (Cleveland et al., 1980). All cDNA probes were purified using a Magic PCR Prep DNA Purification Kit (Promega, Madison, WI, U.S.A.).

\section{RNase protection}

Riboprobes were prepared from cDNA templates following the manufacturer's protocol (Promega). An exon 3 rat genomic IGF-I fragment was kindly provided by Dr. Peter Rotwein (Washington University, St. Louis, MO, U.S.A.). The rat IGF-I receptor cDNA, inserted in pGEM3, yields a protected band of 265 bp after hybridization (Werner et al., 1989). Probes were prepared and RNase protection performed as described previously, using 10- $\mu \mathrm{g}$ RNA samples (Martin et al., 1991).

\section{Immunohistochemistry}

For immunohistochemical studies, three animals at each time point were examined following sciatic nerve transection. After they were killed, animals were perfused with 4\% paraformaldehyde in $0.1 M$ phosphate buffer ( $\mathrm{pH} \mathrm{7.3)}$ ). Proximal and distal nerve stumps and the contralateral control nerves were dissected and postfixed an additional $3 \mathrm{~h}$ at $4^{\circ} \mathrm{C}$. Portions of sciatic nerves within $1 \mathrm{~cm}$ proximal or distal to the cut site were cryoprotected with sucrose and embedded in OCT (Miles), frozen above liquid nitrogen, and stored at $-80^{\circ} \mathrm{C}$. Sections $(12 \mathrm{~mm})$ were cut on a cryostat, thaw mounted onto Tespa-coated slides (Pierce Chemicals, Rockford, IL, U.S.A.), and stored at $-20^{\circ} \mathrm{C}$.

Polyclonal rabbit anti-human IGF-I antibody (UB3-189) was obtained from the NIDDK, National Hormone and Pituitary Program by Drs. Louis E. Underwood and Judson J. Van Wyk (University of North Carolina, Chapel Hill, NC, U.S.A.) and used at 1:1,000 in phosphate buffer. Rabbit antibodies raised against IGFBP-5 were purchased from Upstate Biotechnology (Lake Placid, NY, U.S.A.), and used at 1:500. Frozen sections were processed for immunostaining employing an immunoperoxidase procedure using the chromogen 3,3'-diaminobenzidine as described previously (Sullivan and Feldman, 1994). IGF-I-immunoreactive specificity 
was tested by use of either preimmune rabbit serum or primary antibody preabsorbed with excess recombinant IGF-I ( $1 \mu \mathrm{g} / \mathrm{ml}$; BioSource, Camarillo, CA, U.S.A.).

Anti-IGFBP-5 is a polyclonal antiserum raised against human IGFBP-5 with low cross-reactivity against other IGFBPs. This antiserum can recognize both human and rat IGFBP-5. IGFBP-5 immunoreactivity was blocked by preabsorption of the antiserum with recombinant human IGFBP$5(1 \mu \mathrm{g} / \mathrm{ml}$; Austral Biologicals, San Ramon, CA, U.S.A.).

\section{Cell culture}

MT4HI rat SCs were maintained in DMEM containing $10 \%$ FBS, $100 \mu M \mathrm{ZnSO}_{4}$, and $100 \mu \mathrm{g} / \mathrm{ml} \mathrm{G} 418$ at $37^{\circ} \mathrm{C}$ in a humidified atmosphere with $10 \% \mathrm{CO}_{2}$. Upon reaching $80 \%$ confluency, cells were subcultured with trypsin-EDTA into T75 flasks. In some experiments, cells were grown in defined glial cell medium, designated G3, containing $50 \mu \mathrm{g} / \mathrm{ml}$ transferrin, $10 \mathrm{ng} / \mathrm{ml}$ biotin, and $30 \mathrm{n} M$ selenium in DMEM (Bottenstein, 1985).

\section{Cell proliferation assays}

Cells were washed twice and plated with DMEM containing $0.3 \%$ FBS at a density of $3 \times 10^{4} \mathrm{cells} / \mathrm{cm}^{2}$ in $96-$ well plates in increasing concentrations of IGF-I $(0.1,0.3$, 1 , and $3 \cap M)$. Cell proliferation was measured at 6,24 , and $48 \mathrm{~h}$ after plating with the MTT [3-(4,5-dimethylthiazol2-yl)-2,5-diphenyltetrazolium bromide] colorimetric assay (Hansen et al., 1989).

\section{[ methyl- $\left.{ }^{3} \mathrm{H}\right]$ Thymidine $\left(\left[{ }^{3} \mathrm{H}\right] \mathrm{TdR}\right)$ incorporation studies}

MT4HI cells were plated in 6 -well plates $\left(2.5 \times 10^{4}\right.$ cells $/ \mathrm{cm}^{2}$ ) in DMEM with $10 \%$ FBS and allowed to grow for 2 days. Medium was removed, and cells were rinsed twice with DMEM and incubated with increasing concentrations of IGF-I $(0,1$, and $3 \mathrm{n} M)$ for $24 \mathrm{~h}$ at $37^{\circ} \mathrm{C}$. After 24 h, $\left[{ }^{3} \mathrm{H}\right] \mathrm{TdR}(6 \mu \mathrm{Ci}, 6,700 \mathrm{Ci} / \mathrm{mol}$; NEN Du Pont $)$ was added to each well for a 2 -h incubation at $37^{\circ} \mathrm{C}$, and cells were processed as described previously (Feldman and Randolph, 1991)

\section{Northern analysis}

SCs were plated ( $3 \times 10^{6}$ cells per T75 flask) in DMEM and $10 \%$ FBS. After 2 days, the medium was removed, and cells were rinsed twice in DMEM and placed in G3 media only ( $\mathrm{G} 3$ control) or $\mathrm{G} 3$ media containing increasing concentrations $(1,3$, and $10 \mathrm{n} M)$ of IGF-I or des (1-3) IGF-I. Des( $1-3)$ IGF-I is an IGF-I analogue with a sixfold higher affinity for the IGF-I receptor but a lower affinity for the IGFBPs compared with IGF-I (Cascieri et al., 1991). After $24 \mathrm{~h}$, the culture media were collected, RNA was isolated, and northern analysis and densitometry were performed as described previously (Martin and Feldman, 1993).

\section{Western ligand blotting}

Western ligand blots on conditioned media were prepared as described previously (Feldman and Randolph, 1994). Rinsed membranes were air dried and either placed directly on photostimulable storage phosphorimaging plates and scanned using a phosphorimager (Molecular Dynamics PhosphorImager, Sunnyvale, CA, U.S.A.) or exposed to XOmat film (Eastman Kodak, Rochester, NY, U.S.A.) at $-80^{\circ} \mathrm{C}$ for $1-7$ days in the presence of an intensifying screen.

\section{Immunoblotting}

Samples of concentrated conditioned media $(50 \mu \mathrm{g}$ of protein) were mixed at a 5:1 ratio with $10 \times$ sodium dodecyl sulfate-sample buffer [100 $\mathrm{m} M$ Tris ( $\mathrm{pH} 8$ ), $10 \mathrm{~m} M$ EDTA, $10 \%$ sodium dodecyl sulfate, $100 \mathrm{~m} M$ dithiothreitol, $0.1 \%$ bromophenol blue, and $20 \%$ glycerol], and immunoblots were prepared, incubated for $2 \mathrm{~h}$ with IGFBP-5 antiserum $(1: 1,000)$, and visualized with enhanced chemiluminescence using the method of Siciliano and colleagues (1992).

\section{Protease activity experiments}

SC conditioned media were collected as described above. Briefly, confluent SC monolayer was washed twice, then incubated in G3 media without growth factors, and collected after a 24-h incubation. The protease activity experiments were performed in cell-free conditions: $100 \mathrm{ng}$ of recombinant human IGFBP-5 was added to $50 \mu \mathrm{l}$ of DMEM or conditioned media in the presence or absence of $10 \mathrm{n} M$ IGFI. Samples were incubated at $37^{\circ} \mathrm{C}$ for 2,6 , or $24 \mathrm{~h}$, then separated by sodium dodecyl sulfate-polyacrylamide gel electrophoresis under reducing conditions. Western immunoblot analysis using IGFBP-5 antiserum was performed as described above.

\section{RESULTS}

\section{IGF-I and IGF-I receptor expression following nerve transection}

To examine IGF-I and IGF-I receptor gene expression during wallerian degeneration, we isolated RNA from proximal and distal nerve stumps 3 and 7 days after nerve transection. Nerves from $10-12$ animals were pooled for each time point in each experiment, with the uncut contralateral sciatic nerve serving as the control. We detected low levels of IGF-I and IGFI receptor $\mathrm{mRNA}$ in total, uncut sciatic nerves at each time point (Fig. 1 A and B). Following nerve transection, there was an increase in IGF-I gene expression in both the proximal and distal stumps, with maximal IGF-I expression observed in the distal stump at 7 days (Fig. 1A). IGF-l receptor signal also increased in both stumps after nerve transection; however, there was no obvious difference between day 3 and day 7 (Fig. 1B).

To determine which cell type expressed IGF-I in the transected nerve model, we employed immunohistochemistry using anti-IGF-I antiserum. Currently, an antibody to rat IGF-I receptor is not available; therefore, we were unable to perform similar cellular immunolocalization of the receptor. In normal nerves, IGFI staining was primarily present on SCs, fibroblasts, and capillary endothelial cells. In transverse sections, immunoreactive IGF-I was present in SC cytoplasm, forming a rim around the unstained myelin sheath (Fig. 2A). The proximal stumps of both day 3 and day 7 displayed a pattern of IGF-I immunoreactivity similar to intact nerves.

In the distal stumps 3 days after transection, morphological profiles characteristic of nerve injury were observed, including swollen axons and an increased number of endoneurial cells. IGF-I immunoreactivity 


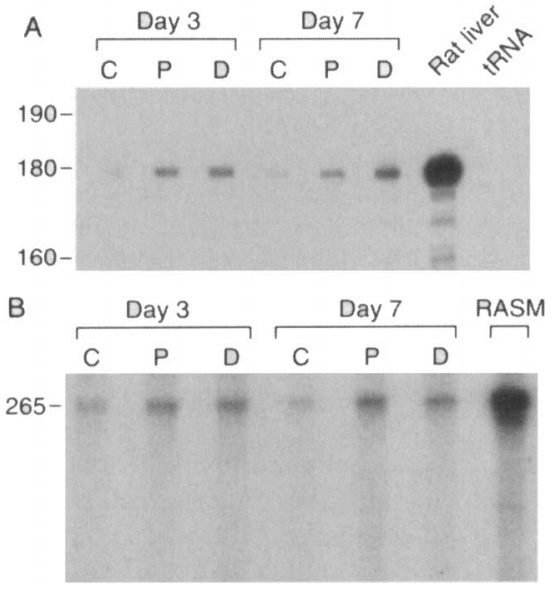

FIG. 1. IGF-I and IGF-I receptor expression following sciatic nerve transection. RNA was isolated from proximal $(P)$ and distal (D) nerve stumps 3 and 7 days after sciatic nerve transection, as described in Materials and Methods. Nerves from 10-12 animals were pooled for each time point in each experiment. A: IGF-I RNase protection assay. An anti-sense RNA probe was transcribed from a 1-kb segment of the IGF-I gene that contained 182 bp of exon-3. Liver RNA protected the appropriate size fragment, whereas RNA from the uncut control nerve (C) produced a barely detectable fragment. Autoradiograph was exposed for 3 days. Data are from one of three representative experiments. B: IGF-I receptor RNase protection. An anti-sense RNA probe was transcribed from a 293-bp IGF-I receptor CDNA. Rat aortic smooth muscle (RASM) RNA protected the expected 265-bp fragment, whereas RNA from the uncut control nerve (C) produced a barely detectable fragment. RNA from nerve proximal (P) and distal (D) to the cut protected the expected 265-bp fragment at 3 and 7 days, with enhanced protection distal to the cut (D) at 7 days. Autoradiograph was exposed for 2 days. Data are from one of two representative experiments. was detected in SCs, fibroblasts, and capillary endothelial cells (Fig. 2B). IGF-I immunoreactivity was not observed when the antiserum was preabsorbed with excess recombinant IGF-I, indicating antiserum specificity (data not shown).

Seven days after nerve transection, the pattern of IGF-I immunoreactivity continued. In addition, macrophages, which were strongly IGF-I positive, appeared within the endoneurial space and along the perineurial border, especially in the distal nerve stumps (Fig. 2D). The IGF-I immunoreactivity within SCs as well as other cellular components remained. In the distal stumps at 7 days, most axons had already degenerated; however, SCs ensheathing axonal debris could still be recognized (Fig. 2C). The quantity of S-100-positive cells rose significantly, indicating SC proliferation. In comparison with the proximal stumps and the control, IGF-I immunoreactivity decreased within the distal stump by day 7 . However, more IGF-I-positive macrophages were detected (Fig. 2D), suggesting macrophages are the primary source of IGF-I at this later time point.

\section{IGF-I promotes SC growth and DNA synthesis}

In vitro models provide a valuable means of assessing growth factor action on specific cell types. To understand better the role of the IGF axis in the PNS, we employed cultured MT4H1 SCs, a rat cell line in which synthetic promoter elements from the mouse metallothionein-I promoter control the expression of SV40 T antigen. This cell line resembles untransfected secondary $\mathrm{SC}$ in both morphology and expression of $P_{0}$ and glial fibrillary acidic protein (Peden et al., 1989; Knight et al., 1993).

IGF-I is mitogenic in both neuronal and glial cells
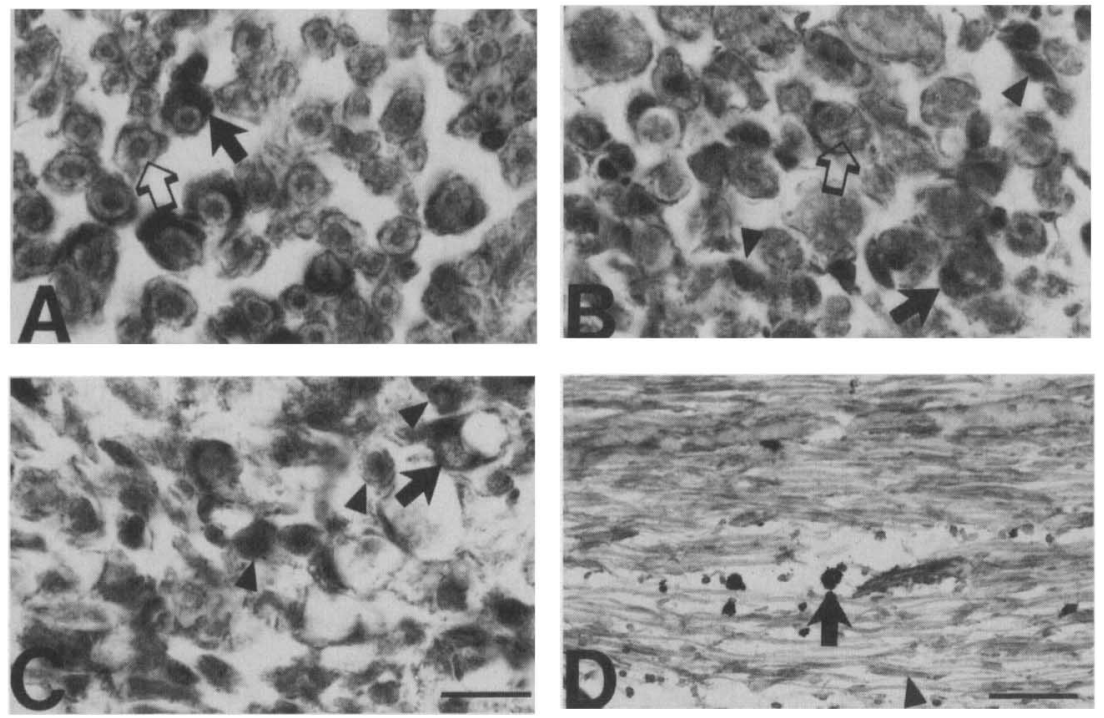

FIG. 2. $|G F-|$ immunoreactivity after nerve transection. Rat sciatic nerves were transected and IGF-I immunohistochemistry was performed 3 and 7 days after surgery using polyclonal antiserum for IGF-I. A: IGF-| immunoreactivity in intact nerves. SCs (arrows) were immunostained, but not the myelin sheath (white arrow). B: IGF-I immunoreactivity at the distal stump at 3 days. Both SCs (arrow) and endoneurial cells (arrowheads) were IGF-I positive. Axonal degeneration was observed (white arrow). C: IGF-I immunoreactivity in distal nerve stumps at 7 days. Axonal degeneration was prominent. IGF-I-immunopositive SC either wrapped around axonal debris (arrow) or were proliferating (arrowheads). D: Longitudinal section of 7-day distal stump. Invading macrophages (arrow, D) appeared to be a major IGF-I source at this point. Less IGF-I immunoreactivity remained within SCs (arrowhead). Sections were representative of nerves of three animals with similar results. Bar $=20 \mu \mathrm{m}\langle$, $\mathrm{B}, \mathrm{C}$ ), or $100 \mu \mathrm{m}$ (D). 
(DiCicco-Bloom and Black, 1988; McMorris and Dubois-Dalca, 1988; Mozell and McMorris, 1988). To determine the effects of IGF-I on SC mitogenesis, SCs were grown in DMEM with $0.3 \%$ FBS with increasing concentrations of IGF-I for 3 days and cell number was determined by MTT assay (Hansen et al., 1989). IGF-I at 0.1 and $0.3 \mathrm{n} M$ had no effect on growth at 6 and $24 \mathrm{~h}$, but a modest effect was noted at $48 \mathrm{~h}$ compared with cells grown in $0.3 \%$ FBS alone. However, at 1 and $3 \mathrm{n} M$ IGF-I, doses known to stimulate glial and neuroblast proliferation (DiCicco-Bloom and Black, 1988; McMorris and Dubois-Dalcq, 1988; Mozell and McMorris, 1988), IGF-I increased cell number within $6 \mathrm{~h}$ with a subsequent dose-dependent increase at 24 and $48 \mathrm{~h}$ (Fig. 3A). We next examined the effect of IGF-I on $\left[{ }^{3} \mathrm{H}\right]$ thymidine incorporation as a reflection of DNA synthesis. As observed with the MTT assay, IGF-I enhanced $\left[{ }^{3} \mathrm{H}\right]$ thymidine incorporation threefold after $24 \mathrm{~h}$ (Fig. 3B). These resuits demonstrate that IGF-I is mitogenic in MT4HI SCs; however, although these data support the concept that IGF$I$ is mitogenic in primary $\mathrm{SCs}$, they must be interpreted with caution because the current experiments were performed on transfected SCs only.

\section{IGF-I and IGF-I receptor expression in cultured SCs}

We speculated that cultured SCs would express IGF$I$ and IGF-I receptor mRNA similar to the results we observed in the transected sciatic nerve of the rat. To explore this possibility, RNA was isolated from cells grown in serum, defined G3 media, or G3 media with increasing concentrations of IGF-I (Peden et al,, 1989; Knight et al., 1993). IGF-I mRNA was not detected with northern analysis or RNase protection (data not shown). As with the transected sciatic nerve preparation, MT4H1 SCs expressed mRNA for the IGF-I receptor (Fig. 4).

\section{Effects of IGF-I on IGFBP gene and protein expression}

The IGFBPs play an integral role in the expression and action of the IGFs (Elgin et al., 1987; Clemmons, 1991: Shimasaki and Ling, 1991; Rosenfeld et al., 1993 ). Multiple neuronal and glial cell lines, including astrocytes, express one or more IGFBPs at the gene and protein level (McCusker et al., 1990; Cheung et al., 1991; Clemmons, 1991). We initially examined IGFBP expression by western ligand blotting in MT4H1 SCs grown in defined G3 media for $24 \mathrm{~h}$. When ${ }^{125}$ I-IGF-II was used as the ligand, two IGFBPs with molecular mass estimates of 31 and $24 \mathrm{kDa}$ were detected ( see Fig. 5A). In contrast, the 24-kDa IGFBP could not be detected by ${ }^{125} \mathrm{I}-\mathrm{IGF}-\mathrm{I}$ (Fig. 5B). The estimated molecular masses suggested that the $31-\mathrm{kDa}$ band corresponded to IGFBP-5 and the 24-kDa band to IGFBP-4 or IGFBP-6 (Adamo et al., 1992; James et al., 1993; Jones et al., 1993). IGF-I treatment increased the intensity of the $31-\mathrm{kDa}$ band in a dose-
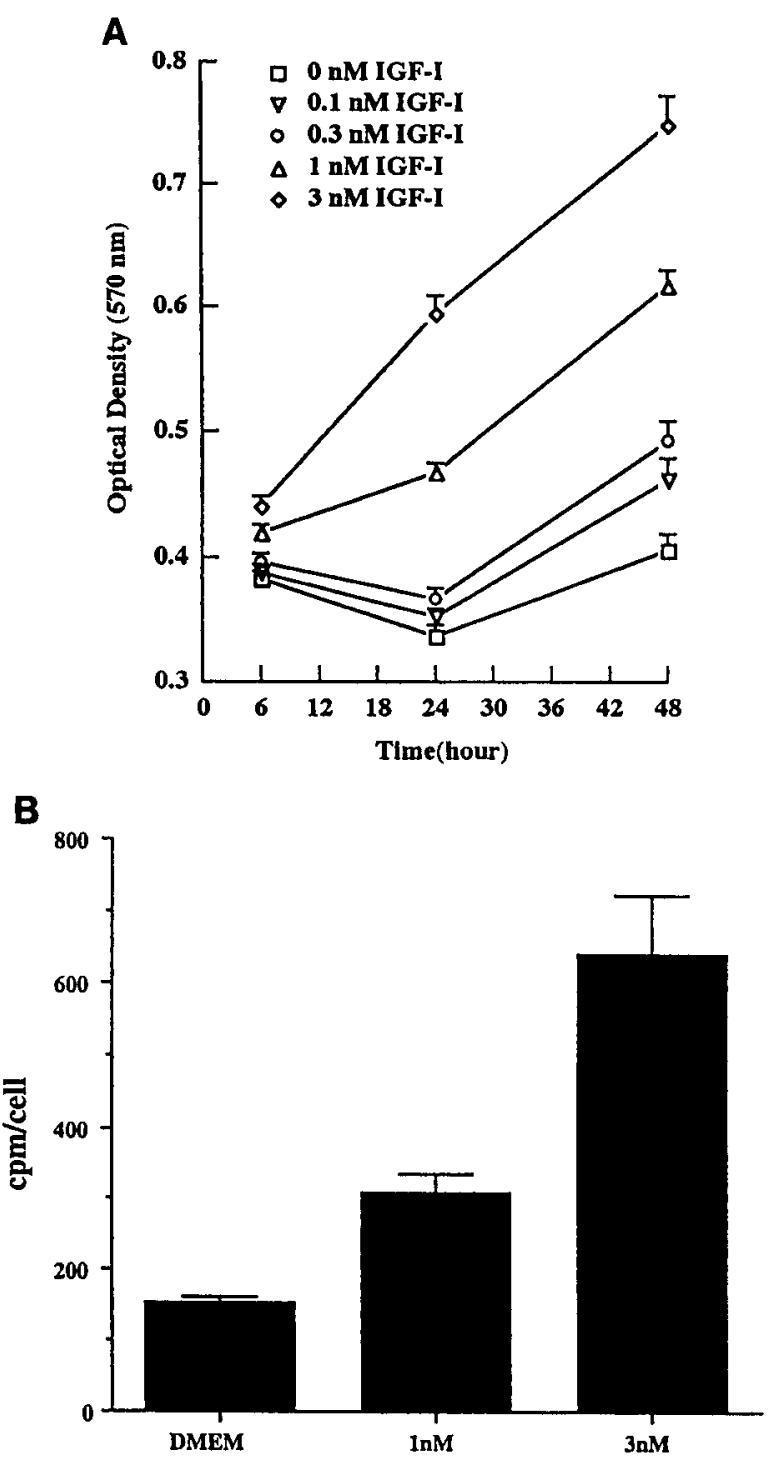

FIG. 3. IGF-I enthances SC proliferation. A: Cells were rinsed and plated in 96-well plates $\left(3 \times 10^{4} \mathrm{cells} / \mathrm{cm}^{2}\right)$ in DMEM containing $0.3 \% \mathrm{FBS} \pm \mathrm{IGF}-\mathrm{I}$. Cell number was measured by MTT assay after 6,24 , or $48 \mathrm{~h}$. Relative optical density $(570 \mathrm{~nm})$ values are means of eight wells \pm SEM. Cell number was significantly higher at each time with 1 and $3 \mathrm{nM}$ IGF-I treatment and at 48 -h treatments ( $\rho<0.05$ compared with $0 \mathrm{n} M$ IGF-I values, by unpaired, two-tailed $t$ test). All data are from representative experiments performed three times. B: Effects of IGF-I on $\left[{ }^{3} \mathrm{H}\right]$ TdR incorporation. Cells were plated at $2.5 \times 10^{4} \mathrm{cells} / \mathrm{cm}^{2}$ in $\mathrm{DMEM}+10 \%$ FBS for 2 days, then rinsed in DMEM and treated with DMEM \pm IGF-I. [ $\left.{ }^{3} \mathrm{H}\right] \mathrm{TdR}$ incorporation and viable cell number (determined by trypan blue dye exclusion) were measured in parallel wells after $24 \mathrm{~h}$. Values in $B$, expressed as counts per minute per cell, are means of triplicate wells \pm SEM. All data are from representative experiments performed three times.

dependent fashion compared with untreated cells with no change in the 24-kDa form (Fig. 5A). To verify the identity of the $31-\mathrm{kDa}$ form of IGFBP, an immunoblot was probed with an IGFBP-5 antibody. Under reducing conditions, the immunoblot for IGFBP-5 re- 


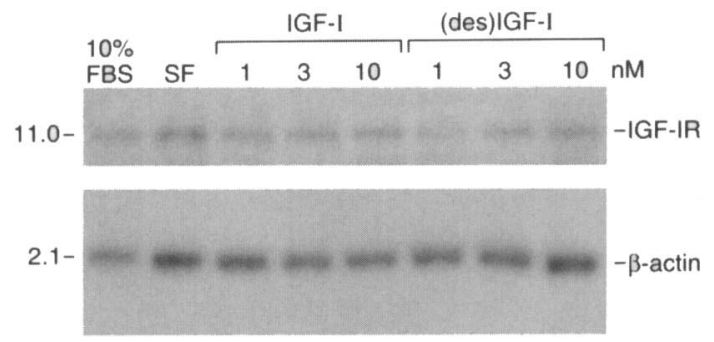

FIG. 4. Northern analysis of IGF-I receptor (IGF-IR) in MT4HI SC. MT4H1 SC were plated at $4 \times 10^{4}$ cells $/ \mathrm{cm}^{2}$ in DMEM $+10 \%$ FBS. After 2 days, the medium was removed and the cells were placed in G3 media $+1,3$, or 10 nM IGF-I. Northern analysis on $20 \mu \mathrm{g}$ of RNA was performed with ${ }^{32} \mathrm{P}$-labeled CDNA probes for IGF-IR, IGFBP-5, and $\beta$-actin, as indicated in Materials and Methods. RNA transcript sizes in kilobase units are listed at the left of the autoradiogram. Autoradiograph was exposed for 7 days. Data are from one of three representative experiments.

vealed a $23-\mathrm{kDa}$ band that exhibited a dose-dependent expression in response to IGF-I treatment (Fig. 5C).

IGF-I enhancement of IGFBP-5 expression in SC conditioned media could represent an IGF-I receptormediated event or, alternatively, IGF-I protection of IGFBP-5 from proteolysis (Conover and Kiefer, 1993; Conover et al., 1993). To distinguish between these two possibilities, cells were treated with an IGF-I analogue, des ( 1-3) IGF-I, that has a sixfold higher affinity for the IGF-I receptor but reduced affinity for IGFBPs (Cascieri et al., 1991). Des(1-3) IGF-I treatment of SCs decreased the level of measurable IGFBP- 5 compared with IGF-I treatment (Fig. 5D). This implies that IGF-I enhances the presence of IGFBP-5 via a receptor-independent mechanism (Conover et al., 1993 ). Finally, equal amounts of protein were electrophoresed for each treatment, making it unlikely that changes in cell number were responsible for the differences observed in the amount of detectable IGFBP-5.

Because IGF-I can alter IGFBP gene expression in multiple cell lines (Krywicki and Yee, 1992), we next examined the effect of IGF-I and IGF analogue treatment on MT4H1 SC IGFBP-5 gene expression. Northern blots were prepared from cells treated for $24 \mathrm{~h}$ in G3 media alone or with the addition of 1,3 , or $10 \mathrm{n} M$ IGF-I or des (1-3)IGF-I. Changes were not observed in the 6.0-kb IGFBP-5 transcript with these treatments (Fig. 6).

\section{IGFBP-5 proteolysis in SC conditioned media}

To demonstrate further that IGF-I enhances the presence of IGFBP-5 via a receptor-independent mechanism, we examined the effect of IGF-I on IGFBP-5 stability in cell-free MT4HI SC conditioned media. rhIGFBP-5 (100 ng) was incubated in $50 \mathrm{ml}$ of either DMEM alone (control) or MT4H1 SC-conditioned media in the presence or absence of $10 \mathrm{n} M$ IGF-I (Fig. 7). After $2 \mathrm{~h}$ of incubation, a single 34-kDa band was detected in the control, corresponding to the published
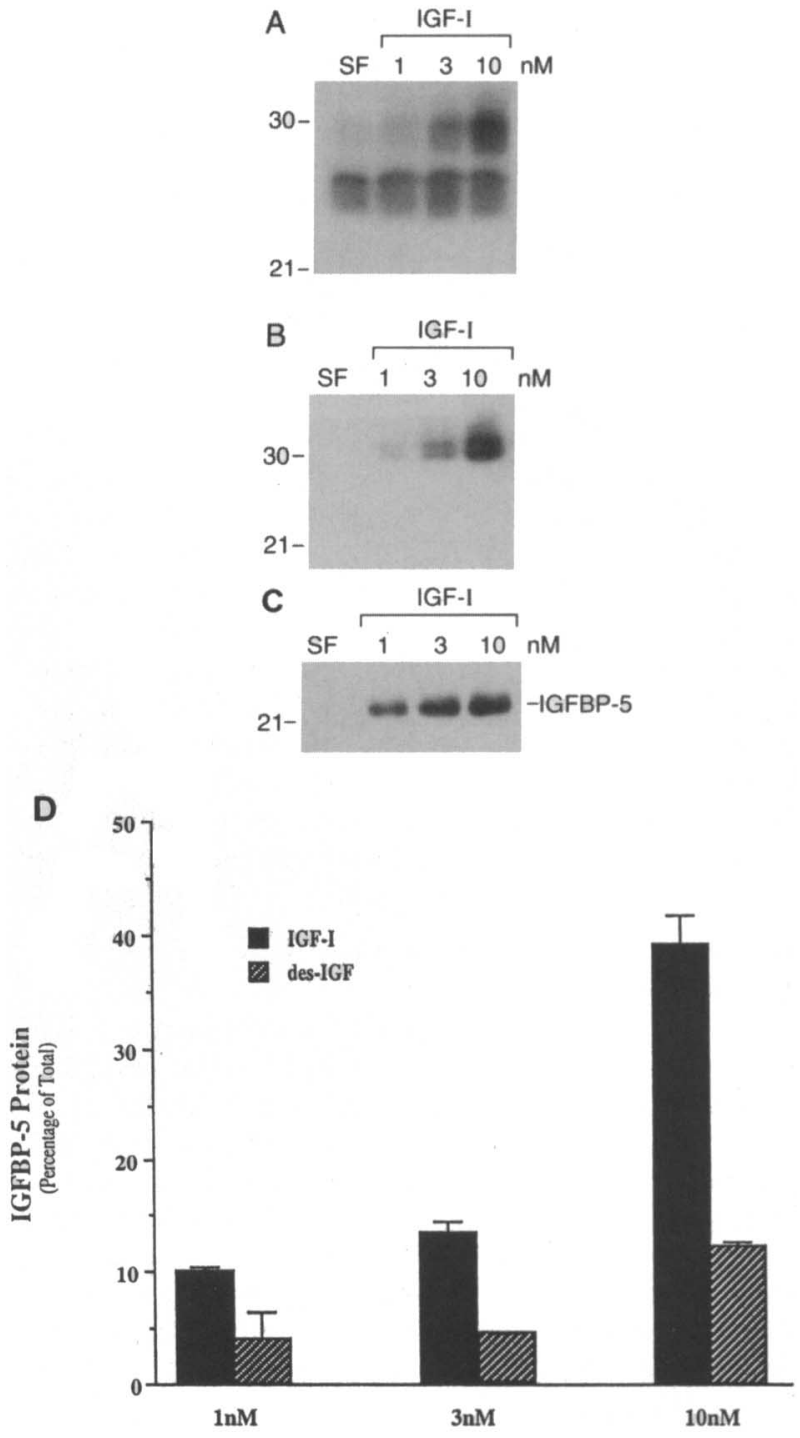

FIG. 5. IGFBP profile after IGF-I or des(1-3)|GF-I treatment. MT4H1 SC were plated at $4 \times 10^{4}$ cells $/ \mathrm{cm}^{2}$ in DMEM $+10 \%$ FBS. After 2 days, the medium was removed and the cells were placed in G3 media $\pm 1,3$, or $10 \mathrm{nM}$ IGF-I, or des(1-3)|GF-I. After $24 \mathrm{~h}$, the media were collected and western ligand blot analysis was performed as described in Materials and Methods. Data are from one of three representative experiments. A: Western ligand blot analysis after IGF-I treatment. Using ${ }^{125}$ |-IGF-II as the ligand, a dose-dependent increase was observed in a 31$\mathrm{kDa}$ form with no change observed in a 24-kDa form under nonreducing condition. Autoradiograph was exposed for 5 days. B: The 31-kDa form was resolved into 29/31-kDa doublet when samples were electrophoresed on $12.5 \%$ sodium dodecyl sulfate-polyacrylamide gel. The $24-\mathrm{kDa}$ form IGFBP was not detected when ${ }^{125}$ I-IGF-I was the ligand. Autoradiograph was exposed for a week. C: Immunoblot of IGFBP-5. A similar dosedependent pattern was observed on IGFBP-5 immunoblot. IGFBP-5 migrated to $23 \mathrm{kDa}$ under reducing conditions. D: Phosphorimaging analysis of western ligand blots. Western ligand blots were placed directly on a photostimulable storage phosphorimaging plate and scanned using a phosphorimager. The percentage of counts in the total scan was determined from three separate experiments and the results are expressed as a percentage of total counts \pm SEM. 

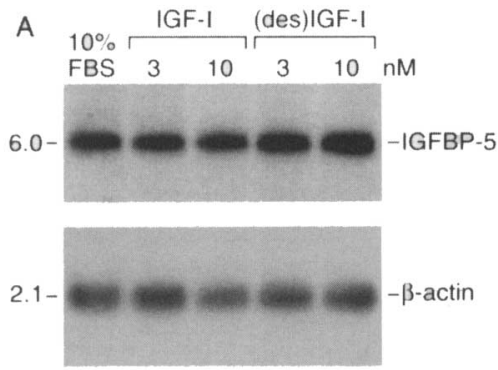

B

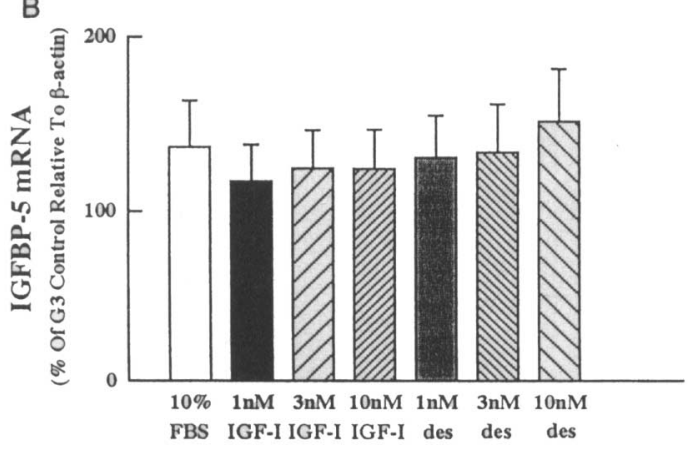

FIG. 6. Northern analysis of IGFBP mRNA after IGF-I and des (1 3)|GF-1 treatment. MT4H1 SC were plated at $4 \times 10^{4} \mathrm{cells} / \mathrm{cm}^{2}$ for 2 days in DMEM $+10 \%$ FBS, rinsed in DMEM as outlined in Materials and Methods, and then treated with 3 or $10 \mathrm{nM}$ IGF-I or des(1-3) IGF-I. A: Autoradiograph from northern blot of IGFBP-5 and $\beta$-actin mRNA. RNA was isolated $24 \mathrm{~h}$ after treatment. Northern analysis on $20-\mu \mathrm{g}$ RNA samples was performed with ${ }^{32} \mathrm{P}$-labeled cDNA probes for IGFBP-5, and $\beta$-actin, as indicated in Materials and Methods. RNA transcript sizes in kitobase units are listed at the left of each autoradiograph. Autoradiographs were exposed for 3 days (GFBP-5) and 1 day ( $\beta$-actin). B: Densitometric analyses of IGFBP- 5 mRNA. Autoradiographs from multiple exposures of the experiments shown in $A$ and at least one additional experiment were quantitated using relative optical densities, as described in Materials and Methods. Values are means \pm SEM of the ratio of IGFBP- 5 mRNA relative optical density to $\beta$-actin relative optical density, expressed as percentage of serum-free untreated control.

molecular mass for rhIGFBP-5 under reducing conditions (Fig. 7, lane d) (Kiefer et al., 1992; Conover and Kiefer, 1993). The same band was also present in the conditioned media after $2 \mathrm{~h}$ with or without $10 \mathrm{nM}$ IGF-I treatment with similar densities to the control (Fig. 7, lanes $b$ and c). After $6 \mathrm{~h}$ of incubation, the same 34-kDa band was present in the control (Fig. 7, lane $h$ ) and in the conditioned media treated with IGFI (Fig. 7, lane g). In contrast, in untreated conditioned media, a $23-\mathrm{kDa}$ band appeared after $6 \mathrm{~h}$ of incubation and coincided with decreased density of the $34-\mathrm{kDa}$ band (Fig. 7, lane f). These data imply that IGF-I protects IGFBP-5 from proteolysis by an IGFBP-5 protease, in agreement with previous reports (Conover and Keifer, 1993; Conover et al., 1993; Clemmons et al., 1994).

\section{IGFBP expression in transected nerves}

To demonstrate that SCs also express IGFBP-5 in vivo, we examined IGFBP-5 immunoreactivity in the transected nerve model. Similar to IGF-I immunostaining, IGFBP-5 immunoreactivity was detected in SCs (Fig. 8A, arrows) as well as axons (Fig. 8A, white arrows ) in intact nerves. Reaction product was homogeneously distributed throughout the SC cytoplasm with an intense rim of immunostaining in intact sciatic nerve. Unlike IGF-I, IGFBP-5 immunoreactivity of $\mathrm{SC}$ s was not influenced by nerve transection. IGFBP5 immunoreactivity remained localized within SCs in the proximal and distal stumps 3 days after transection (Fig. 8B and C). The IGFBP-5 antiserum also stained proliferating SCs in the distal stump on day 7 (Fig. 8D). In contrast, the axonal IGFBP-5 immunoreactivity faded after nerve transection (compare Fig. 8A and $B$ ).

\section{DISCUSSION}

The IGF family of ligands, receptors, and binding proteins is instrumental in normal nervous system development (Daughaday and Rotwein, 1989; Liu et al., 1991 ) and in the repair of nervous tissues (Sjoberg and Kanje, 1989; Jennische and Matejka, 1992; Near et al., 1992; Fernyhough et al., 1993). In this study, we examined the pattern of IGF-I and IGF-I receptor gene expression after sciatic nerve transection. In both proximal and distal nerve segments, we observed increased IGF-I and IGF-I receptor transcripts, with a selective enhancement of IGF-I mRNA in the nerve segment distal to the lesion. Immunohistochemical examination of transected nerves confirmed the presence of IGF-I production by SCs. Our findings parallel those

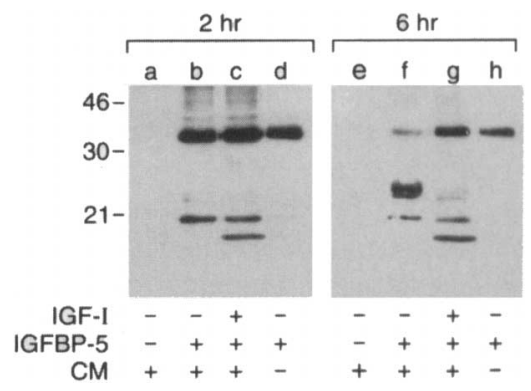

FIG. 7. IGFBP-5 immunoblots revealed IGF-I protection of IGFBP-5 from proteolysis in SC conditioned media (CM). SC conditioned media $(50 \mu \mathrm{l})$ were incubated with or without 100 $\mathrm{ng}$ of rhlGFBP-5 in the presence or absence of $10 \mathrm{nM}$ IGF-I at $37^{\circ} \mathrm{C}$ for 2 or $6 \mathrm{~h}$. The samples were separated by sodium dodecyl sulfate-polyacrylamide gel electrophoresis under reducing conditions, followed by immunoblotting for IGFBP-5. IGFBP-5 was undetectable in SC conditioned media $(a, e)$. There was no difference between the $34-\mathrm{kDa}$ IGFBP-5 intensities of the conditions with (c) or without (b) IGF-I in SC conditioned media after $2 \mathrm{~h}$ of incubation. In contrast, obvious degradation was observed after $6 \mathrm{~h}$ of incubation. The intensity of the 34-kDa band without IGF-I ( $f$ ) decreased significantly in comparison with the conditions plus IGF-I or positive control $(\mathrm{g}, \mathrm{h})$ accompanying the appearance of a $23-k D a$ proteolytic fragment $(f)$. Data are from one of the three experiments with similar results. 

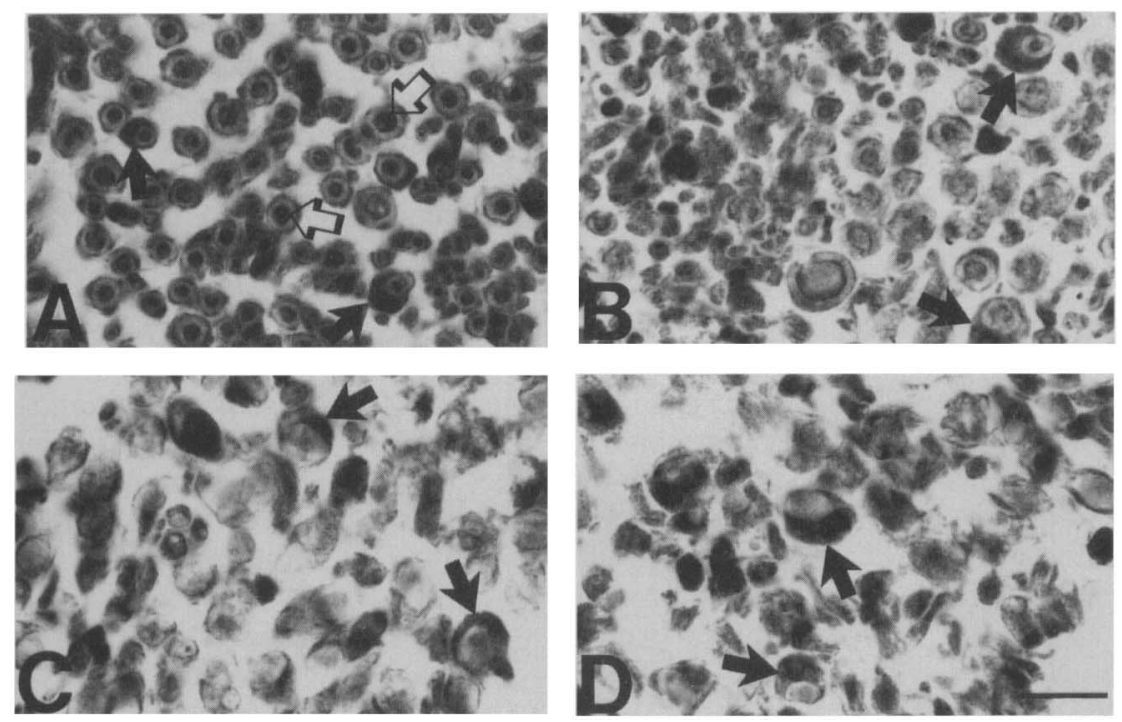

FIG. 8. IGFBP-5 immunoreactivity in nerve transection model. IGFBP-5 immunohistochemistry studies were performed using a polyclonal antiserum against IGFBP-5. A: Intact nerve section. B: Proximal nerve stump of 3 days. C: Distal nerve stump of 3 days. D: Distal nerve stump of 7 days. The IGFBP-5 immunoreactivity was consistently detected in SC cytoplasm (black arrows, $A, B, C, D$ ) as well as axons in intact nerves ( $A$, white arrows). Representative sections are from three animals. Bar $=20 \mu \mathrm{m}$. of Hansson and colleagues who observed patterns of enhanced SC production of IGF-I with peripheral nerve injury (Hansson et al., 1986).

Similar to our results with IGF-I and IGF-I receptors, SCs, including those that ensheathe motor axons, increase production of nerve growth factor (NGF) and NGF receptors following nerve injury (Taniuchi et al., 1986, 1988; Heumann et al., 1987). Transection of selective ventral roots entering the sciatic nerve results in increased NGF receptor expression by SCs associated with degenerating motor neurons, but not intact sensory neurons (Taniuchi et al., 1988). Like IGF$I$ and NGF, transforming growth factor- $\beta$ expression increases with nerve transection, particularly in the distal nerve stump (Scherer et al., 1993). In contrast, the expression of ciliary neurotrophic factor, which is axon dependent, decreases in the distal stumps of transected nerves (Friedman et al., 1992).

We also found that IGF-I promoted in vitro SC growth in a dose-dependent manner. Several polypeptide growth factors are mitogenic to $\mathrm{SC}$ in vitro, including transforming growth factor- $\beta$, acidic and basic fibroblast growth factors, and platelet-derived growth factor (Eccleston, 1992). These factors elevate intracellular cyclic AMP which, in the presence of serum, results in SC proliferation (Eccleston, 1992). Highdose insulin can substitute for serum in the presence of both fibroblast growth factor and platelet-derived growth factor and the cyclic AMP agonist, forskolin (Eccleston, 1992). Because the mitogenic effects of high-dose insulin are mediated via the IGF-I receptor (Flier et al., 1986), the growth-promoting effects of insulin on SC suggest not only the presence of IGF-I receptors on $\mathrm{SC}$ but also a physiological role for IGFI in SC growth.

$\mathrm{SC}$ may not be the sole source of polypeptide growth factors in the PNS. Trophic factors may also be pro- duced by different cell types present in transected nerves, including macrophages, endothelial cells, and fibroblasts (Blexrud et al., 1990). In the current study, we found that macrophages, which infiltrate injured nerves and remove the tissue debris, serve as another source of IGF-I. It is interesting that activated macrophages not only remove tissue debris but also promote $\mathrm{SC}$ growth. In vitro, conditioned media of cultured macrophages activated by phagocytosis of myelin debris promote cultured SC growth via mitogenic peptide factors (Baichwal et al., 1988). Our results suggest one of these mitogenic peptide factors could be IGFI, which was highly expressed by macrophages in the distal stump 7 days after nerve transection. In contrast to the expression of both IGF-I and the IGF-I receptor by $\mathrm{SC}$ in vivo, we did not observe IGF-I gene expression in vitro in MT4HI SC in the current study. These observations imply that (a) the ability of SCs to express IGF-I in vivo is lost in vitro; (b) the observed in vivo expression of IGF-I within SCs of the cut nerve is secondary to other IGF-I-producing cells, including fibroblasts (Clemmons and Van Wyk, 1985), endothelial cells (Delafontaine and Lou, 1993; Fath et al., 1993), and/or macrophages (Nagaoka, 1990); (c) the IGF-I immunoreactivity in nerve sections is either receptor or binding protein associated; (d) IGF-I immunoreactivity decreases in the distal stumps at 7 days indicate that the ability of SC to express IGF-I is axon dependent. An IGF-I in situ hybridization study of the proximal and distal nerve stumps as well as the neurons of the spinal cord and dorsal root ganglia would be one way to distinguish between these possibilities.

We did observe IGF-I receptor expression in MT4HI SC. These data parallel our findings on IGFI receptor expression in proximal and distal transected sciatic nerve segments. Collectively, our results support the concept that one role of growth factor receptors 
on SC surfaces is to present growth factors to regenerating axons, e.g., IGF-I binding to the IGF-I receptor is one means by which SC could increase the local bioavailability of IGF-I to regenerating axons.

An alternative means of presenting IGF-I to regenerating axons is via the IGFBPs. In the current study, we speculated that SCs secrete IGFBPs which, in turn, bind to SC plasmalemmal matrix and serve as reservoirs for IGF-I. Immunohistochemical studies demonstrated the presence of IGFBPs in the SCs of transected nerves. We then determined whether IGFBPs were produced by MT4H1 SC. Utilizing western ligand blots, immunoblots, and northern analysis, we report that MT4H] SCs secrete IGFBP-5 and a 24-kDa IGFBP which, according to the molecular mass, could be IGFBP-4 or IGFBP-6 (Kiefer et al., 1992). The evidence that this 24-kDa IGFBP can be detected only by the ligand ${ }^{125}$ I-IGF-II suggests it is IGFBP-6 because IGFBP-6 binds preferentially to IGF-II and cannot always be detected by ligand blots using ${ }^{125}$ I-IGFI (Kiefer et al., 1992).

Although the precise mechanisms remain unknown, IGFBP-5 is associated with cellular growth and differentiation (Mohan et al., 1989; Andress and Birnbaum, 1992; James et al., 1993; Jones et al., 1993). In vitro, IGFBP-5 regulates osteoblast proliferation (Mohan et al., 1989; Andress and Birnbaum, 1992), and expression of IGFBP-5 markedly increases during muscle cell differentiation (James et al., 1993). It is likely that IGFBP modulation of IGF bioavailability underlies the profound effects IGFBPs have on growth. Recently, Clemmons and colleagues have demonstrated that IGFBP-5 can bind to fibroblast ECM and sequester IGF-I for local fibroblast growth (Jones et al., 1993). The ability of ECM components to dissociate IGFBP5 from an IGF-I/IGFBP-5 complex further supports the concept that IGFBP-5 targets IGF-I near cell surface IGF-I receptors. Thus, the interactions between SC ECM, IGFBP-5, and IGF-I receptors may regulate local IGF-I bioavailability (Arai et al., 1994).

In cultured fibroblasts and osteoblasts, IGFBP-5 appears to be a stimulatory factor for IGF's mitogenic effects. Clemmons and colleagues have demonstrated that ECM-associated IGFBP-5 (but not free IGFBP-5 in the media) can potentiate IGF-I's mitogenic effects (Jones et al., 1993). Similarly, a truncated 24-kDa IGFBP-5, isolated from osteoblast-conditioned media, can enhance IGF-I-dependent osteoblast proliferation (Andress and Birnbaum, 1992). The present study reveals the colocalization of IGF-I and IGFBP-5 in a model of nerve transection, implying that IGFBP-5 may play a positive role in modulating IGF-I trophic effects on SC growth, and on axonal regeneration in PNS.

Our experiments also suggest that IGF-I-induced changes in IGFBP-5 are not mediated via the IGF$I$ receptor. Although IGF-I enhanced the presence of IGFBP-5, des (1-3) IGF-I, an analogue that retains the ability to bind the IGF-I receptor but has a marked decreased affinity for the IGFBPs (Forbes et al., 1988), did not increase the concentration of IGFBP5. Thus, an IGF analogue that cannot bind IGFBP-5, but can bind the IGF-I receptor, cannot mimic IGF-I's effects. We also found that IGF-I protected IGFBP-5 from proteolysis in a cell-free system. These data imply that the IGF-I-dependent increased concentration of IGFBP-5 is a receptor-independent phenomenon and represents the protection of an extracellular IGF-I/ IGFBP-5 complex from proteolysis by an IGFBP-5 protease. In agreement with the current results, Conover and colleagues reported that addition of IGF-I enhanced IGFBP-5 levels in vitro in osteosarcomaconditioned media via a receptor-independent mechanism (Conover et al., 1993) and that IGF-I protected IGFBP-5 from proteolysis (Conover et al., 1993; Durham et al., 1994). Similar results were also observed in a fibroblast system by Clemmons and colleagues, and a calcium-dependent serine protease responsible for IGFBP-5 proteolysis has been identified and isolated (Clemmons et al., 1994). Our results suggest the presence of a similar protease that can cleave IGFBP5 into proteolytic fragments in SC conditioned media.

In summary, although recent work (Eccleston, 1992), including the current study, emphasizes the importance of neurotrophic factors in nerve growth, the mechanisms underlying successful axonal regeneration and reformation of axon-SC contacts remain unknown. One theory is that neurotrophins bind to $\mathrm{SC}$ surfaces producing a trophic factor-enriched SC plasmalemmal matrix that enhances axonal regrowth (Eccleston, 1992). The present study supports this concept; we have shown that, to facilitate regeneration in response to nerve injury, SCs produce IGF-I and IGFI receptor. This regenerative process is augmented further by the ability of SCs to secrete IGFBPs, which, in turn, may bind SC basement membrane and increase local IGF-I bioavailability.

Acknowledgment: H-L.C. is supported by MH14279, D.Y. is supported by CA 52592, P.D. is an Established Investigator of the American Heart Association and is supported by HL 47035 and HL 45317, G.T. is supported by NS 21700 and NS 29710, and E.L.F. is supported by NS 01381 and NS 32843. We gratefully acknowledge the use of the phosphorimager in the Michigan Diabetes Research and Training Center, NIH Grant P60 DK20572. The authors would also like to thank Dr. Kelli Sullivan for her careful review of the manuscript and Judy Boldt for expert secretarial assistance.

\section{REFERENCES}

Adamo M. L., Shao Z.-M., Lanau F., Chen J. C., Clemmons D. R., Roberts C. T., Jr., LeRoith D., and Fontana J. A. ( 1992) Insulinlike growth factor-I (IGF-I) and retinoic acid modulation of IGF-binding proteins (IGFBPs): IGFBP-2, -3 , and -4 gene expression and protein secretion in a breast cancer cell line. Endocrinology 131, 1858- 1866 .

Andress D. L. and Birnbaum R. S. ( 1992 ) Human osteoblast-derived 
insulin-like growth factor (IGF) binding protein-5 stimulates osteoblast mitogenesis and potentiates IGF action. J. Biol. Chem. 267, 22467-22472.

Araj T., Parker A., Busby W., Jr., and Clemmons D. R. (1994) Heparin, heparan sulfate, and dermatan sulfate regulate formation of the insulin-like growth factor-I and insulin-like growth factor-binding protein complexes. J. Biol. Chem. 269, 2038820393.

Backstrom M., Hall K., and Sara V. (1984) Somatomedin levels in cerebrospinal fluid from adults with pituitary disorders. Acta Endocrinol. (Copenh.) 107, 171-178.

Baichwal R. R., Bigbee J. W., and DeVries G. H. (1988) Macrophage-mediated myelin-related mitogenic factor for cultured Schwann cells, Proc: Natl. Acad. Sci. USA 85, 1701-1705.

Barreca A., Voci A., Minuto F., De Marchis M., Cecchelli E., Fugassa E., Giordano G., and Gallo G. (1992) Effect of epidermal growth factor on insulin-like growth factor-I ( IGF-I) and IGFbinding protein synthesis by adult rat hepatocytes. $\mathrm{Mol}$. Cell. Endocrinol. 84, 119-126.

Beck F., Samani N. J., Byrne S., Morgan K., Gebhard R., and Brammar W. J. ( 1988) Histochemical localization of IGF-I and IGF-II mRNA in the rat between birth and adulthood. Development 104, 29-39.

Binoux M., Roghani M., Hossenlopp P., Hardouin S., and Gourmelen M. (1991) Molecular forms of human IGF binding proteins: physiological implications. Acta Endocrinol. (Copenh.) 124 (Suppl. 2), $41-47$.

Blexrud M. D., Lee D. A., Windebank A. J., and Brunden K. R. (1990) Kinetics of production of a novel growth factor after peripheral nerve injury. J. Neurol. Sci. 98, 287-299.

Bondy C. A., Werner H., Roberts C. T., Jr., and LeRoith D. (1990) Cellular pattern of insulin-like growth factor-I ( IGF-I) and type I IGF receptor gene expression in early organogenesis; comparison with IGF-II gene expression. Mol. Endocrinol. 4, 13861398.

Bottenstein J. E. (1985) Growth and differentiation of neural cells in defined media, in Cell Culture in the Neurosciences (Bottenstein J. E. and Sato G., eds), pp. 3-43. Plenum Press, New York

Cascieri M. A., Chicchi G. G., and Bayne M. L. (1991) Characterization of the biological activity of $I G F I$ analogs with reduced affinity for IGF receptors and binding proteins. Adv. Exp. Med. Biol. 293, 23-30.

Cheung P. T., Smith E. P., Shimasaki S., Ling N., and Chernausek S. D. (1991) Characterization of an insulin-like growth factor building protein (IGFBP-4) produced by the B 104 rat neuronal cell line: chemical and biological properties and differential synthesis by sublines. Endocrinology 129, 1006-1015.

Chomczynski P. and Sacchi N. (1987) Single-step method of RNA isolation by acid guanidinium thiocyanate-phenol-chloroform extraction. Anal. Biochem. 162, 156-159.

Chou C. K., Dull T. J., Russell D. S., Gherzi R., Lebwohl D., Ulirich A., and Rosen O. M. (1987) Human insulin receptors mutated at the ATP-binding site lack protein tyrosine kinase activity and fail to mediate postreceptor effects of insulin. J. Biol. Chem. 262, 1842-1847.

Clemmons D. R. (1989) Structural and functional analysis of insulin-like growth factors. Br. Med. Bull. 45, 465-480.

Clemmons D. R. ( 1991 ) Insulin-like growth factor binding proteins: roles in regulating IGF physiology. J. Dev. Physiol. 15, 105110.

Clemmons D. R. and Van Wyk J. J. ( 1985 ) Evidence for a functional role of endogenously produced somatomedin-like peptides in the regulation of DNA synthesis in cultured human fibroblasts and porcine smooth muscle cells. J. Clin. Invest. 95, 19141918

Clemmons D. R., Nam T. J., Busby W. H., and Parker A. (1994) Modification of IGF action by insulin-like growth factor binding protein-5, in The Insulin-Like Growth Factors and Their Regu-
Latory Proteins (Baxter R. C., Gluckman P. D., and Rosenfeld R. G., eds), pp. 183-191. Elsevier Science B. V., Amsterdam. Cleveland D. W., Lopata M. A., MacDonald R. J., Cowan N. J. Rutter W. J., and Kirschner M. W. (1980) Number and evolutionary conservation of a- and b-tubulin and cytoplasmic $b$ - and g-actin genes using specific cloned cDNA probes. Cell 20,95105

Conover C. A. (1991) A unique receptor-independent mechanism by which insulin-like growth factor I regulates the availability of insulin-like growth factor binding proteins in normal and transformed human fibroblasts. I. Clin. Invest. 88, 1354-1361.

Conover C. A. and Kiefer M. C. (1993) Regulation and biological effect of endogenous insulin-like growth factor binding protein5 in human osteoblastic cells. J. Clin. Endocrinol. Metab. 76, $1153-1159$.

Conover C. A., Bale L. K., Clarkson J. T., and Torring O. (1993) Regulation of insulin-like growth factor binding protein-5 messenger ribonucleic acid cxpression and protein availability in rat osteoblast-like cells. Endocrinology 132, 2525-2530.

Daughaday W. H. and Rotwein P. ( 1989 ) Insulin-like growth factor I and II: peptide, messenger ribonucleic acid and gene structures, serum, and tissue concentrations. Endocr. Rev. 10, 68-91.

Delafontaine P. and Lou H. (1993) Angiotensin II regulates insulinlike growth factor I gene expression in vascular smooth muscle cells. J. Biol. Chem. 268, 16866-16870.

DiCicco-Bloom E. and Black I. B. (1988) Insulin growth factors regulate the mitotic cycle in cultured rat sympathetic neuroblasts. Proc. Natl. Acad. Sci. USA 85, 4066-4070.

Drop S. L. S. ( 1992) Report on the nomenclature of the IGF binding proteins. Endocrinology 130, 1736-1737.

Durham S. K., Kiefer M. C., Riggs B. L., and Conover C. A. (1994) Regulation of insulin-like growth factor binding protein 4 by a specific insulin-like growth factor binding protein 4 proteinase in normal human osteoblast-like cells: implications in bone cell physiology. J. Bone Miner. Res. 9, 111-117.

Eccleston P. A. (1992) Regulation of Schwann cell proliferation: mechanisms involved in peripheral nerve development. Exp. Cell Res. 199, 1-9.

Elgin R. G., Busby W. H., and Clemmons D. R. (1987) An insulinlike growth factor binding protein enhances the biologic response to IGF-I. Proc. Natl. Acad. Sci. USA 84, 3254-3258.

Fath K. A., Alexander W., and Delafontaine P. (1993) Abdominal coarctation increases insulin-like growth factor I mRNA levels in rat aorta. Circ. Res. 72, 271-277.

Feldman E. L. and Randolph A. E. (1991) Mannose 6-phosphate potentiates insulin-like growth factor II effects in cultured human neuroblastoma cells. Brain Res. 562, 111-116.

Feldman E. L. and Randolph A. E. (1994) Regulation of insulinlike growth factor binding protein synthesis and secretion in human retinal pigment epithelial cells, J. Cell. Physiol. 158, 198-204.

Fernyhough P., Willars G. B., Lindsay R. M., and Tomlinson D. R. (1993) Insulin and insulin-like growth factor I enhance regeneration in cultured adult rat sensory neurones. Brain Res. 607 , $117-124$.

Flier J. S., Usher P., and Moses A. C. (1986) Monoclonal antibody to the type I insulin-like growth factor (IGF-I) receptor blocks IGF-I receptor-mediated DNA synthesis: clarification of the mitogenic mechanisms of IGF-I and insulin in human skin fibroblasts. Proc: Natl. Acad. Sci. USA 93, 664.

Forbes B., Szabo L., Baxter R. C., Ballard F. J., and Wallace J. C. (1988) Classification of the insulin-like growth factor binding proteins into three distinct categories according to their binding specificities. Biochem. Biophys. Res. Commun. 157, 196-202.

Friedman B., Scherer S. S., Rudge J. S., Helgren M., Morrisey D., McClain J., Wang D., Wiegand S. J., Furth M. E., Lindsay R. M., and Ip N. Y. (1992) Regulation of ciliary neurotrophic factor expression in myelin-related schwann cells in vivo. Neuron 9, 295-305.

Han V. K. M., Lund P. K., Lee D. C., and D'Ercole A. J. (1988) 
Expression of somatomedin/insulin-like growth factor messenger ribonucleic acids in the human fetus: identification, characterization, and tissue distribution. J. Clin. Endocrinol. Metab. 66, 422- 429

Hansen M. B., Nielsen S. E., and Berg K. ( 1989 ) Re-examination and further development of a precise and rapid dye method for measuring cell growth/cell kill. J. Immunol. Methods 119, 203210

Hansson H. A., Dahlin L. B., Danielsen N., Fryklund L., Nachemson A. K., Polleryd P., Rozell B., Skottner A., Stemme S., and Lundborg G. ( 1986 ) Evidence indicating trophic importance of IGF-I in regenerating peripheral nerves. Acta Physiol. Scand. 126, 609-614.

Haselbacher G. K., Schwab M. E., Pasi A., and Humbel R. E. (1985) Insulin-like growth factor II (IGF II) in human brain: regional distribution of IGF II and of higher molecular mass forms. Proc Natl. Acad. Sci. USA 82, 2153-2157.

Heumann R.. Korsching S., Bandtlow C., and Thoenen H. (1987) Changes of nerve growth factor synthesis in nonneuronal cells in response to sciatic nerve transection. J. Cell Biol. 104, 16231631 .

James P. L., Jones S. B., Busby W. H., Jr., Clemmons D. R., and Rotwein P. ( 1993 ) A highly conserved insulin-like growth factor-binding protein (IGFBP-5) is cxpressed during myoblast differentiation. J. Biol. Chem. 268, 22305-22312.

Jennische E. and Matejka G. L. (1992) IGF-I binding and IGF-I expression in regenerating muscle of normal and hypophysectomized rats. Acta Pswchiatr. Scand. 146, 79-86.

Jones J. I., Gockerman A., Busby W. H., Jr., Camacho-Hubner C., and Clemmons D. R. ( 1993 ) Extracellular matrix contains insulin-like growth factor binding protein-5: potentiation of the effects of IGF-1. J. Cell Biol. 121, 679-687.

Kiefer M. C., Schmid C., Waldvogel M., Schläpfer I., Futo E., Masiarz F. R., Green K., Barr P. J., and Zapf J. (1992) Characterization of recombinant human insulin-like growth factor binding proteins 4,5 , and 6 produced in yeast. J. Biol. Chem. 267, $12692-12699$

Knight R. M., Fossom L. H., Neuberger T. J., Attema B. L., Tennekoon G., Bharucha V., and DeVries G. H. (1993) Increased PO glycoprotcin gene expression in primary and transfected rat Schwann cells after treatment with axolemma-enriched fraction. J. Neurosei. Res. 35, 38-45.

Kobayashi S., Clemmons D. R., and Venkatachalam M. A. (1991) Colocalization of insulin-like growth factor-binding protein with insulin-like grow1h factor I. Am. J. Physiol. Renal, Fluid Electrolyte Phwsiol. 261, F22-F28.

Krywicki R. F. and Yee D. (1992) The insulin-like growth factor family of ligands, receptors, and binding proteins. Breast Cancer Res. Treat. 22, 7-19.

Liu F., Powell D. R., Styne D. M., and Hintz R. L. ( 1991) Insulinlike growth factors (IGFs) and IGF-binding proteins in the developing thesus monkey. J. Clin. Endocrinol. Metab. 72, $905-911$.

Lynch S. E., Colvin R. B., and Antoniades H. N. (1989) Growth factors in wound healing: single and synergistic effects on partial thickness porcine skin wounds. J. Clin. Invest. 84, 640646

Martin D. M. and Feldman E. L. ( 1993 ) Regulation of insulin-like growth factor-Il expression and its role in autocrine growth of human neuroblastoma cells. J. Cell. Physiol. 155, 290-300.

Martin D. M., Yee D., and Feldman E. L. (1991) Gene expression of the insulin-like growth factors and their receptors in cultured human retinal pigment epithelial cells. Mol. Brain Res. 12, 181 186

Martin J. L. and Baxter R. C. (1991) Transforming growth factorbeta stimulates production of insulin-like growth factor-binding protein- 3 by human skin fibroblasts. Endocrinology 128, $1425-$ 1433.

Martin J. L., Ballesteros M., and Baxter R. C. (1992) Insulin-like growth factor-I (IGF-I) and transforming growth factor-b1 re- lease IGF-binding protein-3 from human fibroblasts by different mechanisms. Endocrinology 131, 1703-1710.

Matejka G. L. and Jennische E. (1992) IGF-I binding and IGF-I mRNA expression in the post-ischemic regenerating rat kidney. Kidney Int. 42, $1113-1123$.

McCusker R. H., Camacho-Hubner C., Bayne M. L., Cascieri M. A., and Clemmons D. R. (1990) Insulin-like growth factor (IGF) binding to human fibroblast and glioblastoma cells: the modulating effect of cell-released IGF binding proteins (IGFBPs). I. Cell. Physiol. 144, 244-253.

McCusker R. H., Busby W. H., Dehoff M. H., Camacho-Hubner C. and Clemmons D. R. (1991) Insulin-like growth factor (IGF) binding to cell monolayers is directly modulated by the addition of IGF-binding proteins. Endocrinology 129, 939-949.

McMorris F. A. and Dubois-Dalcq M. (1988) Insulin-like growth factor I promotes cell proliferation and oligodendroglial commitment in rat glial progenitor cells developing in vitro. $J$. Neurosci. Res. 21, 199-209.

Mohan S., Bautista C. M., Wergedal J., and Baylink D. J. (1989) Isolation of an inhibitory insulin-like growth factor (IGF) binding protein from bone cell-conditioned medium: a protein local regulator of IGF action. Proc. Natl. Acad. Sci. USA 86, 83388342.

Mozell R. L. and McMorris F. A. (1988) Insulin-like growth factorI stimulates regeneration of oligodendrocytes in vitro. Ann. NY Acad. Sci. 540, 430-432.

Nagaoka I. (1990) Regulation of insulin-like growth factor I gene expression in the human macrophage-like cell line U937. $J$ Clin. Invest. 85, 448 .

Near S. L., Whalen L. R., Miller J. A., and Ishii D. N. ( 1992 ) Insulin like growth factor II stimulates motor nerve regeneration. Proc. Natl. Acad. Sci. USA 89, 11716-11720.

Peden K. W. C., Charles C., Sanders L., and Tennekoon G. I. ( 1989) Isolation of rat Schwann cell lines: use of SV40 T antigen gene regulated by synthetic metallothionein promoters. Exp. Cell Res. $185,60-72$.

Rosenfeld R. G., Lamson G., Pham H., Oh Y., Conover C., De Leon D. D., Donovan S. M. Ocrant I., and Giudice L. ( 1993) Insulinlike growth factor-binding proteins. Recent Prog. Horm. Res. 46, $99-163$.

Sara V. R. and Hall K. (1990) Insulin-like growth factors and their binding proteins. Physiol. Rev: 70, 591-614

Scherer S. S.. Kamholz J., and Jakowlew S. B. (1993) Axons modulate the expression of transforming growth factor-betas in Schwann cells. Glia 8, 265-276.

Shimasaki S. and Ling N. (1991) Identification and molecular characterization of insulin-like growth factor binding proteins (IGFBP-1, -2, -3, -4, -5 and -6). Prog. Growth Factor Res. 3, $243-266$.

Siciliano J. C., Menegoz M., Chamak B., and Girault J.-A. (1992) Antiphosphotyrosine antibodies for studying protein phosphorylation in neural cells: application to brain slices and cultured cells. Neuroprotocols 1, 185-192.

Sjoberg J. and Kanje M. (1989) Insulin-like growth factor (IGF-I) as a stimulator of regeneration in the freeze-injured rat sciatic nerve. Brain Res. 485, $102-108$

Skottner A., Arrhenius-Nyberg V., Kanje M., and Fryklund L. (1990) Anabolic and tissue repair functions of recombinant insulin-like growth factor I. Acta Paediatr. Scand. 367, 63-66.

Smith F. E., Rosen K. M., Villa-Komaroff L., Weir G. C., and Bonner-Weir S. (1991) Enhanced insulin-like growth factor I gene expression in regenerating rat pancreas. Proc. Natl. Acad. Sci. USA 88, 6152-6156.

Steenfos H. H. and Jansson J.-O. ( 1992 ) Gene expression of insulinlike growth factor-I and IGF-I receptor during wound healing in rats. Acta Chirurgica-Eur. J. Surg. 158, 327-331.

Suh D. Y., Hunt T. K., and Spencer E. M. (1992) Insulin-like growth factor-I reverses the impairment of wound healing induced by corticosteroids in rats. Endocrinology 131, 2399-2403.

Sullivan K. A. and Feldman E. L. (1994) Immunohistochemical 
localization of insulin-like growth factor II and insulin-like growth binding protein-2 during development in the rat. Endocrinology 135, 540-547.

Sumantran V. N. and Feldman E. L. (1993) Insulin-like growth factor I regulates c-myc and GAP-43 messenger ribonucleic acid expression in SH-SY5Y human neuroblastoma cells. Endocrinology 132, 2017-2023.

Taniuchi M., Clark H. B., and Johnson E. M. (1986) Induction of nerve growth factor receptor in Schwann cells after axotomy. Proc. Natl. Acad. Sci. USA 83, 4094-4098.

Taniuchi M., Clark H. B., Schweitzer J. B., and Johnson E. J. ( 1988 ) Expression of nerve growth factor receptors by Schwann cells of axotomized peripheral nerves: ultrastructural location, suppression by axonal contact, and binding properties. I. Neurosci. 8, 664-681.

Torring O., Firek A. F., Heath H., III, and Conover C. A. (1991)
Parathyroid hormone and parathyroid hormone-related peptide stimulate insulin-like growth factor-binding protein secretion by rat osteoblast-like cells through an adenosine $3^{\prime}, 5^{\prime}$-monophosphate-dependent mechanism. Endocrinology 128, 10061014.

Unterman T. G., Oehler D. T., Murphy L. J., and Lacson R. G. (1991) Multihormonal regulation of insulin-like growth factorbinding protein-1 in rat H4IIE hepatoma cells: the dominant role of insulin. Endocrinology 128, 2693-2701.

Verstrepen W. A., Nouwen E. J., Yue X. S., and DeBroe M. E. (1993) Altered growth factor expression during toxic proximal tubular necrosis and regeneration. Kidney Int. 43, 1267-1279.

Werner H., Woloschak M., Adamo M.. Shen-Orr Z., Roberts C. T. Jr., and LeRoith D. (1989) Developmental regulation of the rat insulin-like growth factor I receptor gene. Proc. Natl. Acad. Sci. USA 86, 7451-7455. 